\title{
Genetic diversity of group A rotaviruses associated with repeated outbreaks of diarrhea in a farrow-to- finish farm: identification of a porcine rotavirus strain bearing a novel VP7 genotype, G26
}

\author{
Ayako Miyazaki ${ }^{1}$, Kazufumi Kuga ${ }^{1,2}$, Tohru Suzuki ${ }^{1}$, Mariko Kohmoto ${ }^{1}$, Ken Katsuda ${ }^{1}$ and Hiroshi Tsunemitsu ${ }^{1,2^{*}}$
}

\begin{abstract}
Group A rotaviruses (GARs) are one of the most common causes of diarrhea in suckling pigs. Although a number of $G$ and $P$ genotypes have been identified in porcine GARs, few attempts have been made to study the molecular epidemiology of these viruses associated with diarrhea outbreaks within a farm over an extended period of time. Here, we investigated the molecular characteristics of GARs that caused four outbreaks of diarrhea among suckling pigs in a farrow-to-finish farm over the course of a year. $G$ and P genotyping of GARs detected at each outbreak demonstrated genetic diversity in this farm as follows: G9P[23] was detected at the first outbreak, G9P[13]/[22] and G9P[23] at the second, G3P[7] at the third, and G9P[23], G5P[13]/[22], and P[7] combined with an untypeable G genotype at the fourth. Sequence analysis of the detected GARs revealed that such genetic diversity could have resulted not only from the introduction of new GAR strains, but also from gene reassortment between GAR strains within the farm. Further, the GAR strain carrying the untypeable G genotype was shown to be a novel porcine GAR bearing a new G26 genotype, as confirmed by the Rotavirus Classification Working Group.
\end{abstract}

\section{Introduction}

Group A rotaviruses (GARs) are the most common etiological agent of severe diarrhea in infants and young children worldwide, as well as being a common cause of acute enteritis in young farm animals [1]. They are members of the Rotavirus genus, within the Reoviridae family, and their genome consists of 11 segments of double-stranded RNA (dsRNA) encased in a triple-layered capsid. These segments encode six structural (VP1-VP4, VP6, and VP7) and five or six non-structural proteins. Amongst these, the outer capsid proteins VP7 and VP4, which independently elicit the production of neutralization antibodies, define the $\mathrm{G}$ and $\mathrm{P}$ serotypes, and form the basis of a binomial nomenclature [1]. In recent years, the serotype classification system has been almost completely replaced by a genotyping classification system based on sequence differences of the respective gene segments [2,3]. Prior to the present study,

\footnotetext{
* Correspondence: tsunemi@affrc.go.jp

1 Viral Disease and Epidemiology Research Division, National Institute of

Animal Health, 3-1-5 Kannondai, Tsukuba, Ibaraki 305-0856, Japan

Full list of author information is available at the end of the article
}

at least $25 \mathrm{G}$ genotypes and $33 \mathrm{P}$ genotypes were identified in humans and animals $[4,5]$. Among them, at least $11 \mathrm{G}$ genotypes (G1-G6, G8-G12) and $13 \mathrm{P}$ genotypes (P[1], $\mathrm{P}[5]-\mathrm{P}[8], \mathrm{P}[11], \mathrm{P}[13], \mathrm{P}[19], \mathrm{P}[13] /[22], \mathrm{P}[23], \mathrm{P}[26]$, $\mathrm{P}[27]$, and $\mathrm{P}[32])$ have been described in pigs [6-11].

The zoonotic potential of animal GARs is a great concern [12]. GARs with unusual G genotypes commonly found in pigs and cattle have been detected in sporadic and epidemic cases of diarrhea in human populations [13-18]. A full genome-based genotyping system proposed by Matthijnssens et al. revealed the existence of reassortant strains and the close relationship between human and animal strains $[2,3]$. In addition, a number of new $G$ and $P$ genotypes have recently been identified in animals $[4,5,7,19,20]$. In light of these findings, animal GARs have come to be regarded as a potential reservoir for genetic diversity in human GARs, and studying them is therefore critical for understanding the evolution and ecology of human GARs.

Besides their zoonotic potential, as the most frequently detected enteropathogen associated with diarrhea among 
suckling pigs, GARs also pose an economic threat to the pig industry due to poor growth performance, and increased morbidity and mortality rates [21,22]. Given the present lack of a commercially available vaccine for GAR-associated diarrhea in Japan, the only means of prevention has been hygiene management. However, although effectively managing GAR infections requires an ecological understanding of GARs, few attempts have been made to examine the molecular epidemiology of porcine GARs associated with diarrhea within a farm over an extended length of time. We therefore investigated the genotypic characteristics of GARs causing repeated outbreaks of diarrhea among suckling pigs in a farrow-to-finish farm over the course of a year.

\section{Materials and methods Fecal samples}

Outbreaks of epidemic diarrhea occurred among suckling pigs four times between February 2009 and March 2010 at a large farrow-to-finish farm with 4000 sows located in the Miyazaki prefecture, Japan. A total of 28 fecal samples (one sample per litter, 5 to 11 samples per outbreak) were collected from the rectum of diarrheal pigs that had not been treated with antibiotics. All animal experiments were approved by the Animal Ethical Committee and the Animal Care and Use Committee of National Institute of Animal Health.

\section{Bacteriological and parasitological examination}

Bacteriological examinations were carried out for Escherichia coli, Salmonella enterica, and Clostridium perfringens, and parasitological examinations were carried out for Coccidia and Cryptosporidium parvum, as described previously [21].

\section{RNA extraction}

Fecal specimens were diluted with Eagle's minimum essential medium to $10 \%$ suspensions and clarified by centrifugation at $1500 \times g$ for $10 \mathrm{~min}$. The supernatant was collected and total RNA was extracted from $250 \mu \mathrm{L}$ of the fecal suspensions using TRIzol LS (Invitrogen Corp., Carlsbad, CA, USA). Recovered total RNA was suspended in $50 \mu \mathrm{L}$ of RNase/DNase-free water and stored at $-20^{\circ} \mathrm{C}$ until use for reverse transcription-polymerase chain reaction (RT-PCR) and polyacrylamide gel electrophoresis (PAGE).

\section{RNA-PAGE}

PAGE of the extracted RNA was performed with $7.5 \%$ precast gels (e-PAGEL; Atto Corp., Tokyo, Japan). The gels were stained using a Silver Stain Plus kit (Bio-Rad Laboratories, Hercules, CA, USA). GAR electropherotypes were determined by comparing the individual RNA migration patterns of genome segments on the gel [23]

\section{RT-PCR}

The GAR VP7 gene and the VP8* fragment of the VP4 gene were amplified using a QIAGEN OneStep RT-PCR kit (Qiagen, Valencia, CA, USA) with primer pairs Beg9/ End9 and Con2/Con3, respectively [24,25]. RT-PCR was conducted to detect group $\mathrm{B}$ and $\mathrm{C}$ rotaviruses (GBRs and GCRs), transmissible gastroenteritis virus, porcine epidemic diarrhea virus, and porcine sapovirus as described previously [26-30]. The amplicons were analyzed in $2 \%$ agarose gel electrophoresis and visualized by UV after ethidium bromide staining.

\section{DNA sequencing and genetic analysis}

The amplicons of the GAR VP7 and VP4 genes were purified using MicroSpin S-400 HR Columns (GE Healthcare, Uppsala, Sweden). The purified PCR products were used as a template for sequencing on an Applied Biosystems 3100 automated DNA sequencer using Dye terminator cycle sequencing chemistry (Applied Biosystems, Foster City, CA, USA) and sequenced from both directions. To determine the complete coding region of the VP7 gene of a TJ4-1 strain, primers TJ4-1 494F (5'-GTA ACC CAA TGG ACA TTA CAC TG-3') and TJ4-1 368R (5'-CTA CTG AAA ATG ATG CGA TGT C-3') were also used as sequencing primers. The sequences were assembled, edited, and analyzed using MEGA 4 software [31]. The nucleotide sequences of the VP7 and VP4 genes from the detected GARs were compared with those of reference strains available in the GenBank. Multiple nucleotide sequence alignments were carried out using the CLUSTAL W algorithm. Genetic distances were calculated using the Kimura-2 correction parameter, and phylogenic dendrograms were constructed by the neighbor-joining method with 1000 bootstrap replications [2].

\section{Nucleotide sequence accession numbers}

The nucleotide sequences determined in this study have been submitted to GenBank under the following accession numbers: TJ1-1 (VP7:AB611688, VP4: AB621582); TJ2-1 (VP7:AB611689, VP4:AB621587); TJ2-2 (VP7:AB611690, VP4:AB621583); TJ3-2 (VP7:AB611692, VP4:AB621585); TJ4-1(VP7:AB605258, VP4:AB621586); TJ4-3 (VP4: AB611691, VP4:AB621584); TJ4-5 (VP7:AB611693, VP4: AB621588).

\section{Results}

Four outbreaks of GAR-associated diarrhea

Epidemic outbreaks of diarrhea affecting almost all suckling pigs born to $20 \%$ to $30 \%$ of lactating sows occurred in February, March, and May 2009, and March 2010. Common clinical signs included profuse watery diarrhea and dehydration lasting about one week. Mortality rates were less than $5 \%$. Age and sow parity of the sampled pigs are summarized in Table 1 . While no 
Table 1 Number, age, and sow parity of the sampled pigs at each of the four outbreaks of diarrhea on a large farrow-to-finish farm

\begin{tabular}{lllll}
\hline Outbreak & $\begin{array}{l}\text { Month-year } \\
\text { occurred }\end{array}$ & $\begin{array}{l}\text { Number of } \\
\text { sampled pigs }\end{array}$ & \multicolumn{2}{l}{ Range (median) of } \\
\cline { 3 - 5 } & & Days of age & Sow parity \\
\hline 1 & February 2009 & 11 & $4-10(7)$ & $1-7(4)$ \\
2 & March 2009 & 5 & $6-20(9)$ & $1-8(6)$ \\
3 & May 2009 & 5 & $2-5(4)$ & $1-1(1)$ \\
4 & March 2010 & 7 & $3-7(5)$ & $1-3(1)$ \\
\hline
\end{tabular}

pattern was observed for the first two outbreaks, the third and fourth outbreaks mostly affected pigs less than seven days old that were born to gilts.

More than $80 \%$ of the samples collected at each outbreak were positive for GARs, as determined by RTPCR targeting VP7, and are listed in Table 2. A small minority of samples contained other enteropathogens: GBR was detected in two samples at the first outbreak, Isospora suis and Eimeria porci were detected in one sample at the second outbreak, and GCR was detected in one sample at the fourth outbreak. These results indicate that GAR was the most common enteropathogen associated with the repeated outbreaks of diarrhea and most likely the cause as well.

\section{Electropherotypes of the detected GARs}

All 11 segments of GAR genomic RNA were visualized in 22 samples out of the 28 samples subjected to RNA-PAGE. These RNA migration patterns were classified into six electropherotypes designated eI to eVI (Figure 1). All electropherotypes displayed a long migration pattern resembling that of the porcine OSU strain (a reference porcine GAR strain). A different electropherotype was observed in each outbreak, as summarized in Table 2. RNA-PAGE found no samples to be infected with more than one GAR strain, although combined infection of GAR and GBR was observed in two samples (data not shown).

\section{Genetic analysis of GAR VP7 genes and identification of a} novel G genotype

The nucleotide sequences of the VP7 gene (933 bp, corresponding to nucleotides 69 through 1001 of the porcine

Table 2 Electropherotype and combination of G and P genotypes of GAR strains detected in samples collected at each diarrheal outbreak

\begin{tabular}{|c|c|c|c|c|}
\hline \multirow{2}{*}{$\frac{\text { Outbreak }}{1}$} & \multirow{2}{*}{$\begin{array}{l}\text { Sample name } \\
\text { TJ1-1 }\end{array}$} & \multirow{2}{*}{$\begin{array}{l}\text { Electropherotype } \\
\mathrm{el}\end{array}$} & \multicolumn{2}{|c|}{ Combination of $\mathrm{G}$ and $\mathrm{P}$ genotypes } \\
\hline & & & G9 & $\mathrm{P}[23]$ \\
\hline & TJ1-2 & el & G9 & $\mathrm{P}[23]$ \\
\hline & TJ1-3 & el & G9 & nd \\
\hline & TJ1-6 & $--^{a)}$ & $n d^{b)}$ & nd \\
\hline & TJ1-7 & - & G9 & $P[23]$ \\
\hline & TJ1-8 & el & G9 & $P[23]$ \\
\hline & TJ1-9 & el & G9 & nd \\
\hline & TJ1-10 & el & G9 & $P[23]$ \\
\hline & TJ1-11 & el & G9 & $P[23]$ \\
\hline \multirow[t]{4}{*}{2} & TJ2-1 & ell & G9 & $P[13] /[22]$ \\
\hline & TJ2-2 & el & G9 & $P[23]$ \\
\hline & TJ2-3 & el & nd & nd \\
\hline & TJ2-4 & ell & nd & nd \\
\hline \multirow[t]{5}{*}{3} & TJ3-1 & elll & nd & nd \\
\hline & TJ3-2 & elll & G3 & $P[7]$ \\
\hline & TJ3-3 & elll & nd & nd \\
\hline & TJ3-4 & elll & G3 & $P[7]$ \\
\hline & TJ3-5 & elll & nd & nd \\
\hline \multirow[t]{6}{*}{4} & TJ4-1 & elV & $\mathrm{G} 26^{\mathrm{C})}$ & $P[7]$ \\
\hline & TJ4-2 & elV & nd & nd \\
\hline & TJ4-3 & $\mathrm{eV}$ & G9 & $P[23]$ \\
\hline & TJ4-4 & eV & nd & nd \\
\hline & TJ4-5 & $\mathrm{eVl}$ & G5 & $P[13] /[22]$ \\
\hline & TJ4-6 & $\mathrm{eV}$ & nd & nd \\
\hline
\end{tabular}

a) The sample was negative for GAR by RNA-PAGE.

b) The sample was positive for GAR by RT-PCR, but the nucleotide sequences could not be determined.

c) New VP7 (G) genotype determined in the present study. 


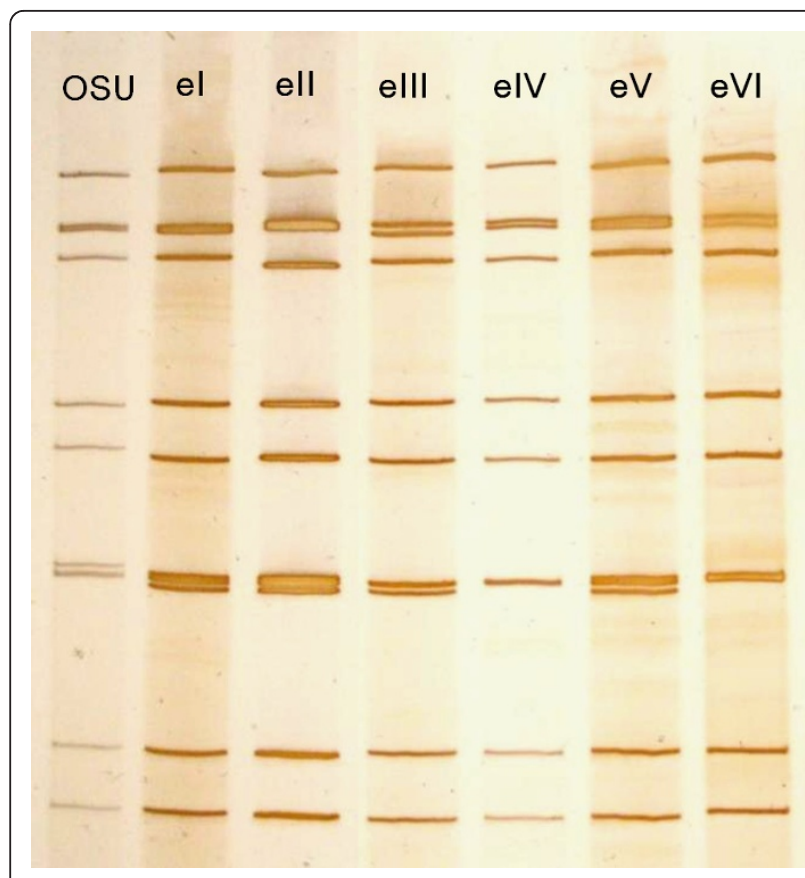

Figure 1 Electropherotypes (el to eVI) of GAR strains detected at each of the four diarrhea outbreaks in a farrow-to-finish farm from February 2009 to March 2010. OSU is a reference porcine GAR strain with a long RNA migration pattern.

G5 OSU strain's VP7 gene) were successfully determined in 15 samples. BLAST search analysis and phylogenic analysis of these VP7 genes with those of 25 established G genotypes led to classification of the 15 GAR strains into four genotypes: G9, G3, G5, and an untypeable G genotype (Figure 2a).

Eleven G9 strains were identified in this study, with eight strains detected at the first outbreak, two at the second, and one at the fourth (Table 2). A phylogenic tree based on a selection of human and animal G9 strains was generated as described by Collins et al. [32]. These eleven strains constituted a separate branch distantly related to human and porcine G9 strains comprising G9 lineages III and VI (Figure 2b). Nucleotide identities for the eleven strains were $99.4 \%$ to $100 \%$ compared to each other, $90.6 \%$ to $93.2 \%$ to the old Japanese porcine G9 isolates JP16-3, JP32-4, JP13-3, JP35-7, JP3-6, JP29-6, and Hokkaido-14 that belong to G9 lineage VI, and $87.2 \%$ to $93.8 \%$ to human and porcine G9 strains belonging to G9 lineages III and VI (Figure 2b and Additional file 1, Table S1).

The two G3 strains TJ3-1 and TJ3-2, both of which were identified at the third outbreak, constituted a separate branch distantly related to porcine G3 strains, comprising lineage I (Figure 2c) [33]. The nucleotide identities of their VP7 genes were $100 \%$ compared to each other, $87.6 \%$ to $91.6 \%$ to the porcine G3 strains comprising lineage I, $87.3 \%$ to $90.9 \%$ to human G3 strains comprising lineage I, and $79.1 \%$ to $82.4 \%$ to the G3 strains comprising other lineages (Figure 2c and Additional file 1, Table S1).

The G5 isolate TJ4-5, identified at the fourth outbreak, constituted a separate branch distantly related to human and porcine G5 strains comprising lineage III (Figure 2d) [34]. The nucleotide identities of its VP7 gene were $86.3 \%$ to $90.3 \%$ compared to the G5 strains comprising lineage III, $85.4 \%$ to $87.4 \%$ to lineage I, and $85.3 \%$ to $87.6 \%$ to lineage II (Figure 2d and Additional file 1, Table S1).

Phylogenic analysis revealed that the untypeable G genotype strain TJ4-1, identified at the fourth outbreak, did not cluster with any reference sequence from the group of 25 G genotypes (Figure 2a). In a BLAST search analysis, the nucleotide identities of its VP7 gene were 93.1\% compared to 57vp7w, the uncommon human G3 strain identified in Thailand (736 bp, [GenBank:DQ674932]) [35], up to $80.5 \%$ to other G3 strains, and up to $78.8 \%$ to the strains of other G genotypes. We therefore characterized the TJ41 strain by analyzing the complete coding sequence of the VP7 gene, which turned out to be 981-bp long and included a predicted protein of 326 amino acids. We compared the nucleotide and deduced amino acid sequences with those from the reference strains of the 25 established G genotypes (Table 3) and found that the highest identity was to the G3 RRV strain (80.2\% nucleotide identity and $87.5 \%$ amino acid identity), with lower nucleotide and amino acid identities to other strains ranging from $61.1 \%$ to $78.1 \%$, and $57.2 \%$ to $85.5 \%$, respectively. The Rotavirus Classification Working Group (RCWG) employs a cutoff value of $80 \%$ nucleotide identity to define a novel G genotype [3], and on submitting the sequence to the RCWG, it was subsequently assigned as a new G genotype: G26.

\section{Genetic analysis of the VP8* fragment of GAR VP4 genes}

The nucleotide sequences of the VP8* fragment of the VP4 genes $(774 \mathrm{bp}$, corresponding to nucleotides 70 through 843 of the porcine P[7] OSU strain's VP4 gene) were successfully determined in 13 of 15 samples in which the VP7 gene sequences had been previously determined. BLAST search analysis and phylogenic analysis of these VP4 genes with those of 33 established P genotypes led to classification of the 13 GAR strains into three genotypes: $\mathrm{P}[23], \mathrm{P}[7]$, and $\mathrm{P}[13] /[22]$ (Table 2).

Eight $\mathrm{P}[23]$ strains were identified, with six strains detected at the first outbreak, one at the second, and one at the fourth (Table 2). These strains had nucleotide identities of $99.7 \%$ to $100 \%$ compared to each other, 91.0\% to the porcine GUB71 strain identified in Japan, and $85.6 \%$ to $89.7 \%$ to other porcine $\mathrm{P}[23$ ] strains (Additional file 2, Table S2).

Two P[7] strains (TJ3-1 and TJ3-2) were identified at the third outbreak and one (TJ4-1) at the fourth, having $99.7 \%$ to $100 \%$ sequence identities with each other. They were clustered in one branch related to the 
Table 3 Comparison of the nucleotide and amino acid sequence identities of the VP7 gene of TJ4-1 strain with those of 25 known G genotypes

\begin{tabular}{|c|c|c|c|}
\hline \multirow[t]{2}{*}{ Strain $^{\text {a) }}$} & \multirow[t]{2}{*}{ GenBank accession number } & \multicolumn{2}{|c|}{ Identity to TJ4-1 strain (\%) } \\
\hline & & Nucleotide & Amino acid \\
\hline $\mathrm{Hu} / \mathrm{KU} / \mathrm{G} 1$ & D16343 & 75.2 & 82.0 \\
\hline $\mathrm{Hu} / \mathrm{S} 2 / \mathrm{G} 2$ & M11164 & 73.8 & 75.2 \\
\hline $\mathrm{Si} / \mathrm{RRV} / \mathrm{G} 3$ & V01546 & 80.2 & 87.5 \\
\hline $\mathrm{Si} / \mathrm{SA} 11 / \mathrm{G} 3$ & EU636932 & 77.7 & 85.3 \\
\hline Po/Gottfried/G4 & X06759 & 72.9 & 74.6 \\
\hline Po/OSU/G5 & X04613 & 76.9 & 81.3 \\
\hline Bo/UK/G6 & X00896 & 74.7 & 82.0 \\
\hline $\mathrm{Ch} / \mathrm{Ch}-2 / \mathrm{G} 7$ & $\times 56784$ & 64.7 & 59.3 \\
\hline $\mathrm{Bo} / \mathrm{A} 5 / \mathrm{G} 8$ & D01054 & 74.8 & 78.0 \\
\hline $\mathrm{Hu} / 116 \mathrm{E} / \mathrm{G} 9$ & L14072 & 77.0 & 81.3 \\
\hline $\mathrm{Bo} / \mathrm{KK} 3 / \mathrm{G} 10$ & D01056 & 74.6 & 80.7 \\
\hline Po/YM/G11 & M23194 & 75.4 & 82.0 \\
\hline $\mathrm{Hu} / \mathrm{L} 26 / \mathrm{G} 12$ & M58290 & 73.6 & 78.9 \\
\hline $\mathrm{Eq} / \mathrm{L} 338 / \mathrm{G} 13$ & D13549 & 75.2 & 79.2 \\
\hline $\mathrm{Eq} / \mathrm{CH} 13 / \mathrm{G} 14$ & D25229 & 78.1 & 81.0 \\
\hline $\mathrm{Bo} / \mathrm{Hg} 18 / \mathrm{G} 15$ & AF237666 & 74.2 & 76.5 \\
\hline $\mathrm{Mu} / \mathrm{EW} / \mathrm{G} 16$ & U08430 & 74.2 & 82.3 \\
\hline $\mathrm{Tu} / \mathrm{Ty}-1 / \mathrm{G} 17$ & S58166 & 64.7 & 60.6 \\
\hline Pi/PO-13/G18 & D82979 & 64.7 & 57.5 \\
\hline $\mathrm{Ch} / 02 \mathrm{~V} 0002 \mathrm{G} 3 / \mathrm{G} 19$ & FJ169861 & 63.1 & 57.2 \\
\hline Hu/Ecu534/G20 & EU805775 & 74.6 & 81.0 \\
\hline Bo/AzuK-1/G21 & AF454421 & 73.5 & 74.6 \\
\hline Tu/Tu-03V0002E10/G22 & EU486973 & 61.1 & 58.3 \\
\hline Ph/Phea17655/Hun/08/G23 & FN393056 & 64.5 & 58.5 \\
\hline Bo/Dai-10/G24 & AB513837 & 71.4 & 73.2 \\
\hline Bat/KE4852/07/G25 & GU983676 & 71.6 & 77.4 \\
\hline
\end{tabular}

a) The reference strains are shown with host species/strain name/G genotype. Abbreviations for host species are shown in the legend of Figure 2 .

b) The highest identity to the reference strain is shown in bold.

porcine OSU strain and in another to porcine and bovine P[7] strains (isolated in China and Korea respectively) with $86.4 \%$ to $94.5 \%$ nucleotide identity (Figure 3 and Additional file 2, Table S2).

In contrast, one $\mathrm{P}[13] /[22]$ strain identified at the second outbreak (TJ2-1) and one at the fourth (TJ4-5) showed low nucleotide identity $(80.3 \%)$ with each other (Additional file 2, Table S2). The TJ2-1 strain belonged to a lineage comprised of porcine $\mathrm{P}[13$ ] strains of Japanese origin (GUB72, FGP28 and FGP36) and global origin (CMP178 and HP140) with $83.3 \%$ to $84.6 \%$ nucleotide identity (Figure 3 and Additional file 2, Table S2). The TJ4-5 strain was clustered with the porcine $\mathrm{P}[13] /[22]$ strains of Ireland origin (2B/05/Ire) and Japanese origin (JP35-7 and JP13-3) with 89.0\% nucleotide identity (Figure 3 and Additional file 2, Table S2).

\section{Combinations of $G$ and $P$ genotypes of GAR strains} detected in the four outbreaks of diarrhea

Based on the sequence and phylogenic analysis of GAR strains detected among the four outbreaks, at least five combinations of $\mathrm{G}$ and $\mathrm{P}$ genotypes (G/P combinations) were identified: G9P [23] at the first outbreak, G9P[13]/ [22] and G9P[23] at the second, G3P[7] at the third, and G26P[7], G9P[23], and G5P[13]/[22] at the fourth (Table 2).

Although the VP7 genes from the G9P[23] and G9P [13]/[22] strains were closely related to each other genetically, they combined with different $\mathrm{P}$ genotypes. Similarly, the VP4 genes from the G3P[7] and G26P[7] strains were highly homologous, yet they combined with different $\mathrm{G}$ genotypes.

\section{Discussion}

Based on fecal analyses, we demonstrated that the cause behind repeated outbreaks of diarrhea among suckling pigs over a one-year period was primarily GAR infection. Sequence and phylogenic analysis of the VP7 and VP4 genes from detected GARs identified a spectrum of $G$ and P genotypes, including G3, G5, G9, P[7], P[13]/[22], and $\mathrm{P}[23]$. In addition, we identified the TJ4-1 strain, which contained a new VP7 genotype G26, as confirmed 


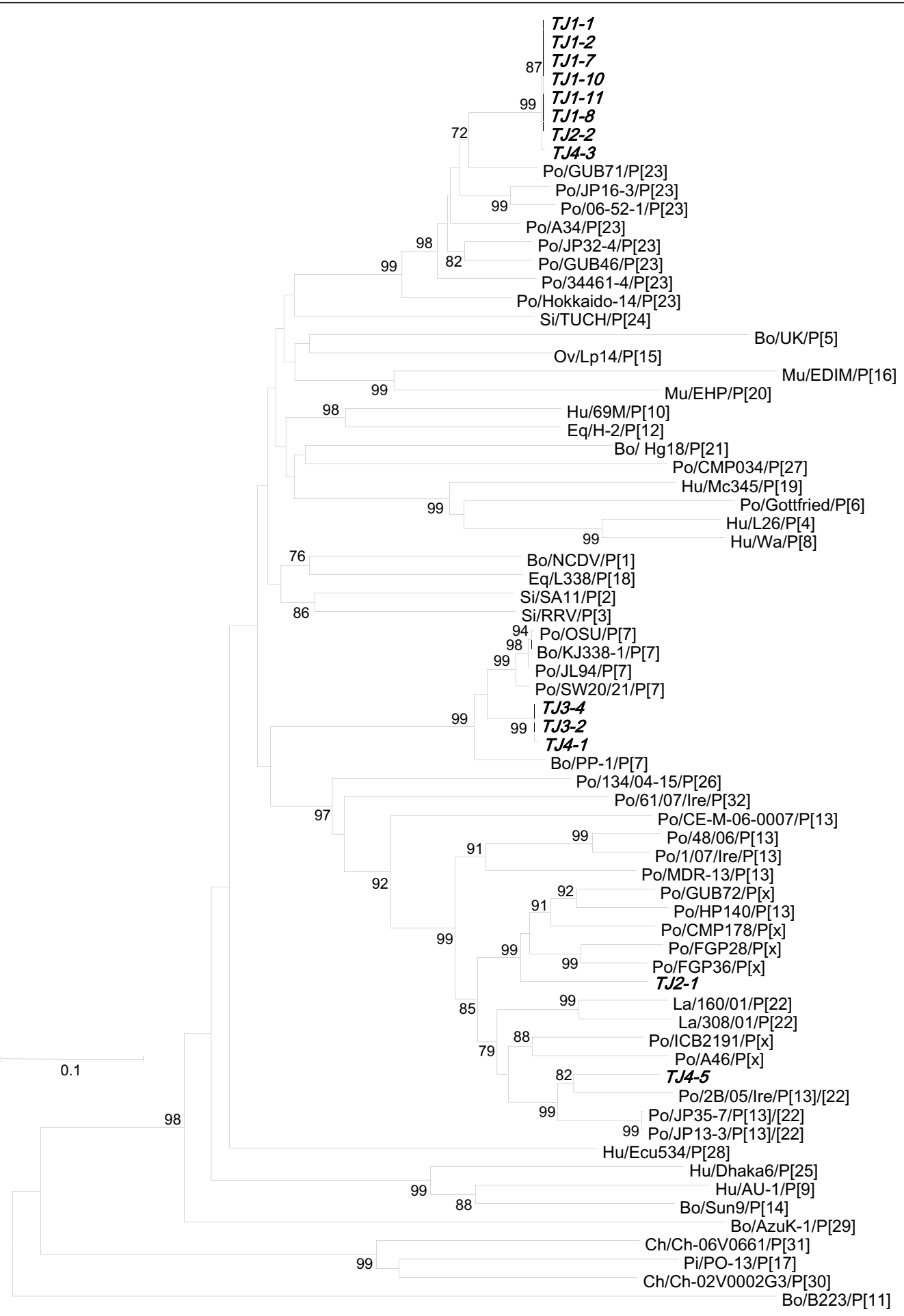

Figure 3 Phylogenic tree based on the partial nucleotide sequences of the VP8* fragment from GAR VP4 genes identified in this study and those of representative strains of each genotype. Bootstrap values above $60 \%$ are shown at the branch nodes. The strains identified in this study are highlighted in bold italic. The strains obtained using GenBank are shown with host species/strain name/genotype. Abbreviations: Hu human, Po porcine, Bo bovine, Ov ovine, La lapine, Si simian, Mu murine, Eq equine, Ch chicken, Pi pigeon, and Tu turkey. The GenBank accession numbers of the strains used in the phylogenic tree are listed in Additional file 2, Table S2. 
and assigned by the RCWG. Although the detected G and $P$ genotypes (excluding G26) were common in pig populations worldwide $[8,32,36,37]$, the strains identified in this study displayed marked genetic variation when compared to others around the world as well as older Japanese strains, suggesting genetic variability in GAR strains circulating in the pig population of Japan.

Several limitations to the present study warrant mention. Not only was the total number of samples low, but also, roughly half of them could not be successfully analyzed for either the VP7 or VP4 genes. However, despite these limitations, we found at least five different G/P combinations and six electropherotypes during the four outbreaks, indicating considerable genetic diversity of GAR strains within a farm continuing over one year. Co-circulation of different GAR strains in the same herd has also been reported in several studies: Collins et al. identified at least 2 to 6 GAR strains among asymptomatic pigs in each farm at a same time [32], and Barreiros et al. detected at least three strains during a diarrhea outbreak on a single swine farm [38]. While such genetic diversity in the same herd may have resulted from the introduction of new GAR strains, our results support the additional possibility of genetic reassortment between GAR strains within the herd. Indeed, the G9P[23] and G9P[13]/[22] strains contained almost identical G9 sequences, and the G3P[7] and G26P[7] strains had nearly identical P[7] sequences.

A previous study has shown that herds with GAR-associated diarrhea tend to be managed in an all-in all-out system and to have large numbers of sows [39]. Because diarrhea occurs in pigs when the oral challenge level of GAR exceeds the protective level of passive immunity acquired through colostrum and milk, the onset age and diarrhea severity are influenced by management practices that affect these factors, such as housing type, sanitation, and crate design [40]. By maintaining strict sanitation management and housing sows and gilts in separate units (about 4000 sows were kept in 8 gestation and 14 farrowing barns), the farm in the present study might reduce the uniformity of exposure levels and immunity to GARs. The variation in affected pigs across the outbreaks appears to reflect the variation in the level of lactogenic immunity passed from sows to piglets (Table 1). Therefore, it cannot be ruled out that differing immunity levels among sows or gilts may be associated with the existence of the genetically diverse GAR strains and the repeated diarrhea outbreaks.

Based on accumulated evidence, it is clear that GARs can transfer between pigs and humans, making pigs a potential reservoir for the emergence of unusual or novel strains of human GARs [13-18]. In fact, the novel G26 strain we found was most similar to the human $57 \mathrm{vp} 7 \mathrm{w}$ strain, which can also be considered to be a G26 strain. The $57 \mathrm{vp} 7 \mathrm{w}$ strain was reported as a rare G3P[19] human strain identified in a clinical sample collected in
Thailand between 2004 and 2006 [35]. Although the origin of G26 remains unclear, the VP4 sequence of 57vp7w [GenBank: DQ674935] is genetically closely related to those of porcine $\mathrm{P}[19]$ strains detected in Thailand [6]. Further, genetic analysis of several genome segments of the TJ4-1 strain other than VP4 and VP7 revealed that, except for the VP7 gene, this strain shares a similar genetic background with the porcine YM strain [Miyazaki A, in preparation]. Taken together, these findings suggest that $57 \mathrm{vp} 7 \mathrm{w}$ may be a porcine-human reassortant or a porcine strain. Considering that the newly identified G26 has been detected in both pigs and humans, and the scarcity of animal GAR strains in the genetic database, further surveillance and epidemiological study on GARs in domestic animals will be needed to better understand the origin and circulation of human GARs.

Here, we demonstrated the genetic diversity of GARs associated with repeated outbreaks of diarrhea among suckling pigs within a farm over a one-year period. Such genetic diversity within a single farm might pose a challenge for developing effective methods of prevention against diarrhea caused by GAR infection.

\section{Additional material}

Additional file 1: Table S1: Comparison of the VP7 genes of the 15 GAR strains identified in this study to those of reference and selected strains. Comparison of the VP7 genes of the 15 GAR strains identified in this study to those of reference strains and a selection of G3, G5 and G9 strains.

Additional file 2: Table S2: Comparison of the VP8* fragment of VP4 genes of the 13 GAR strains identified in this study to those of reference and selected strains. Comparison of the VP8* fragment of VP4 genes of the 13 GAR strains identified in this study to those of reference strains and a selection of $P[7], P[23]$, and $P[13] /[22]$ strains.

\section{Acknowledgements}

Much appreciation is extended to the members of the Rotavirus Classification Working Group for their input regarding strain classification and the identification of the novel VP7 genotype. We appreciate Dr T. Murai's efforts in collecting samples and making helpful suggestions. We would like to thank N. Hattori, H. Kunifuda, and Drs N. Kawanishi, T. Miyamoto, S. Ogawa, and K. Hirano for their technical support. This work was supported in part by a research grant from the National Institute of Animal Health, Japan.

\section{Author details}

${ }^{1}$ Viral Disease and Epidemiology Research Division, National Institute of Animal Health, 3-1-5 Kannondai, Tsukuba, Ibaraki 305-0856, Japan. ${ }^{2}$ The United Graduate School of Veterinary Sciences, Gifu University, 1-1 Yanagido, Gifu 501-1193, Japan.

\section{Authors' contributions}

AM participated in designing the study, carried out the examination and molecular characterizations of GARs, and drafted the manuscript. HT conceived this study and participated in its design and coordination. KK and TS participated in the study design and coordination and carried out the virological examinations. MK and KK participated in designing the study and carried out the parasitological and bacteriological examinations. All authors read and approved the final manuscript. 


\section{Competing interests}

The authors declare that they have no competing interests.

Received: 9 May 2011 Accepted: 9 November 2011

Published: 9 November 2011

\section{References}

1. Estes MK, Kapikian AZ: Rotaviruses. In Fields Virology. Volume 2.. 5 edition. Edited by: David KM, Peter HM. Philadelphia, USA: Lippincott Williams 2007:1917-1974

2. Matthijnssens J, Ciarlet M, Heiman E, Arijs I, Delbeke T, McDonald SM, Palombo EA, Iturriza-Gómara M, Maes P, Patton JT, Rahman M, Van Ranst M: Full genome-based classification of rotaviruses reveals a common origin between human Wa-Like and porcine rotavirus strains and human DS-1like and bovine rotavirus strains. J Virol 2008, 82:3204-3219.

3. Matthijnssens J, Ciarlet M, Rahman M, Attoui H, Bányai K, Estes MK, Gentsch JR, Iturriza-Gómara M, Kirkwood CD, Martella V, Mertens PP, Nakagomi O, Patton JT, Ruggeri FM, Saif LJ, Santos N, Steyer A, Taniguchi K, Desselberger U, Van Ranst M: Recommendations for the classification of group A rotaviruses using all 11 genomic RNA segments. Arch Virol 2008, 153:1621-1629.

4. Esona MD, Mijatovic-Rustempasic S, Conrardy C, Tong S, Kuzmin IV Agwanda B, Breiman RF, Banyai K, Niezgoda M, Rupprecht CE, Gentsch JR, Bowen MD: Reassortant group A rotavirus from straw-colored fruit bat (Eidolon helvum). Emerg Infect Dis 2010, 16:1844-1852.

5. Abe M, Ito N, Masatani T, Nakagawa K, Yamaoka S, Kanamaru Y, Suzuki H, Shibano K, Arashi Y, Sugiyama M: Whole genome characterization of new bovine rotavirus G21P[29] and G24P[33] strains provides evidence for interspecies transmission. J Gen Virol 2011, 92:952-960.

6. Maneekarn N, Khamrin P, Chan-it W, Peerakome S, Sukchai S, Pringprao K, Ushijima H: Detection of rare G3P[19] porcine rotavirus strains in Chiang Mai, Thailand, provides evidence for origin of the VP4 genes of Mc323 and Mc345 human rotaviruses. J Clin Microbiol 2006, 44:4113-4119.

7. Collins PJ, Martella V, Buonavoglia C, O'Shea H: Identification of a G2-like porcine rotavirus bearing a novel VP4 type, P[32]. Vet Res 2010, 41:73.

8. Steyer A, Poljsak-Prijatelj M, Barlic-Maganja D, Marin J: Human, porcine and bovine rotaviruses in Slovenia: evidence of interspecies transmission and genome reassortment. J Gen Virol 2008, 89:1690-1698.

9. Parra Gl, Vidales G, Gomez JA, Fernandez FM, Parreño V, Bok K: Phylogenetic analysis of porcine rotavirus in Argentina: increasing diversity of G4 strains and evidence of interspecies transmission. Vet Microbiol 2008, 126:243-250.

10. Halaihel N, Masía RM, Fernández-Jiménez M, Ribes JM, Montava R, De Blas Gironés $\mathrm{O}$, Alonso JL, Buesa J: Enteric calicivirus and rotavirus infections in domestic pigs. Epidemiol Infect 2010, 138:542-548.

11. Martella V, Ciarlet M, Bányai K, Lorusso E, Cavalli A, Corrente M, Elia G Arista S, Camero M, Desario C, Decaro N, Lavazza A, Buonavoglia C: Identification of a novel VP4 genotype carried by a serotype G5 porcine rotavirus strain. Virology 2006, 346:301-311.

12. Martella V, Bányai K, Matthijnssens J, Buonavoglia C, Ciarlet M: Zoonotic aspects of rotaviruses. Vet Microbiol 2010, 140:246-255.

13. Uchida R, Pandey BD, Sherchand JB, Ahmed K, Yokoo M, Nakagomi T, Cuevas LE, Cunliffe NA, Hart CA, Nakagomi O: Molecular epidemiology of rotavirus diarrhea among children and adults in Nepal: detection of G12 strains with P[6] or P[8] and a G11P[25] strain. J Clin Microbiol 2006, 44:3499-3505.

14. Bok K, Castagnaro N, Borsa A, Nates S, Espul C, Fay O, Fabri A, Grinstein S, Miceli I, Matson DO, Gómez JA: Surveillance for rotavirus in Argentina. $J$ Med Virol 2001, 65:190-198.

15. Esona MD, Geyer A, Banyai K, Page N, Aminu M, Armah GE, Hull J, Steele DA, Glass RI, Gentsch JR: Novel human rotavirus genotype G5P[7] from child with diarrhea, Cameroon. Emerg Infect Dis 2009, 15:83-86.

16. Carmona RC, Timenetsky MoC, da Silva FF, Granato CF: Characterization of rotavirus strains from hospitalized and outpatient children with acute diarrhoea in São Paulo, Brazil. J Med Virol 2004, 74:166-172.

17. Gouvea V, de Castro L, Timenetsky MC, Greenberg H, Santos N: Rotavirus serotype G5 associated with diarrhea in Brazilian children. J Clin Microbiol 1994, 32:1408-1409.

18. Santos N, Lima RC, Pereira CF, Gouvea V: Detection of rotavirus types G8 and G10 among Brazilian children with diarrhea. J Clin Microbiol 1998, $36: 2727-2729$
19. Abe M, Ito N, Morikawa S, Takasu M, Murase T, Kawashima T, Kawai Y, Kohara J, Sugiyama M: Molecular epidemiology of rotaviruses among healthy calves in Japan: isolation of a novel bovine rotavirus bearing new P and G genotypes. Virus Res 2009, 144:250-257.

20. Parra Gl, Galeano ME, Arbiza J: Genetic relationship between porcine rotavirus strains bearing a new P-type. Vet Microbiol 2007, 125:193-195

21. Katsuda K, Kohmoto M, Kawashima K, Tsunemitsu H: Frequency of enteropathogen detection in suckling and weaned pigs with diarrhea in Japan. J Vet Diagn Invest 2006, 18:350-354.

22. Saif $L$, Fernandez FM: Group A rotavirus veterinary vaccines. I Infect Dis 1996, 174(Suppl 1):S98-106.

23. Theil K, McCloskey C, Saif L, Redman D, Bohl E, Hancock D, Kohler E, Moorhead P: Rapid, simple method of preparing rotaviral doublestranded ribonucleic acid for analysis by polyacrylamide gel electrophoresis. J Clin Microbiol 1981, 14:273-280.

24. Gouvea V, Glass Rl, Woods P, Taniguchi K, Clark HF, Forrester B, Fang ZY: Polymerase chain reaction amplification and typing of rotavirus nucleic acid from stool specimens. J Clin Microbiol 1990, 28:276-282.

25. Gentsch JR, Glass RI, Woods P, Gouvea V, Gorziglia M, Flores J, Das BK, Bhan MK: Identification of group A rotavirus gene 4 types by polymerase chain reaction. J Clin Microbiol 1992, 30:1365-1373.

26. Kuga K, Miyazaki A, Suzuki T, Takagi M, Hattori N, Katsuda K, Mase M, Sugiyama M, Tsunemitsu H: Genetic diversity and classification of the outer capsid glycoprotein VP7 of porcine group B rotaviruses. Arch Virol 2009, 154:1785-1795.

27. Tsunemitsu H, Jiang B, Saif L: Sequence comparison of the VP7 gene encoding the outer capsid glycoprotein among animal and human group C rotaviruses. Arch Virol 1996, 141:705-713.

28. Paton D, Ibata G, Sands J, McGoldrick A: Detection of transmissible gastroenteritis virus by RT-PCR and differentiation from porcine respiratory coronavirus. J Virol Methods 1997, 66:303-309.

29. Kim O, Choi C, Kim B, Chae C: Detection and differentiation of porcine epidemic diarrhoea virus and transmissible gastroenteritis virus in clinical samples by multiplex RT-PCR. Vet Rec 2000, 146:637-640.

30. Honma S, Nakata S, Kinoshita-Numata K, Kogawa K, Chiba S: Evaluation of nine sets of PCR primers in the RNA dependent RNA polymerase region for detection and differentiation of members of the family Caliciviridae, Norwalk virus and Sapporo virus. Microbiol Immunol 2000, 44:411-419.

31. Tamura K, Dudley J, Nei M, Kumar S: MEGA4: Molecular Evolutionary Genetics Analysis (MEGA) software version 4.0. Mol Biol Evol 2007, 24:1596-1599.

32. Collins PJ, Martella V, Sleator RD, Fanning S, O'Shea H: Detection and characterisation of group A rotavirus in asymptomatic piglets in southern Ireland. Arch Virol 2010, 155:1247-1259.

33. Martínez-Laso J, Román A, Rodriguez M, Cervera I, Head J, Rodríguez-Avial I, Picazo Jj: Diversity of the $\mathrm{G} 3$ genes of human rotaviruses in isolates from Spain from 2004 to 2006: cross-species transmission and intergenotype recombination generates alleles. J Gen Virol 2009, 90:935-943.

34. da Silva MF, Tort LF, Goméz MM, Assis RM, Volotão EeM, de Mendonça MC, Bello G, Leite JP: VP7 Gene of human rotavirus A genotype G5: Phylogenetic analysis reveals the existence of three different lineages worldwide. J Med Virol 2011, 83:357-366.

35. Theamboonlers A, Bhattarakosol P, Chongsrisawat V, Sungkapalee T, Wutthirattanakowit N, Poovorawan Y: Molecular characterization of group A human rotaviruses in Bangkok and Buriram, Thailand during 20042006 reveals the predominance of G1P[8], G9P[8] and a rare G3P[19] strain. Virus Genes 2008, 36:289-298.

36. Teodoroff T, Tsunemitsu H, Okamoto K, Katsuda K, Kohmoto M, Kawashima K, Nakagomi T, Nakagomi O: Predominance of porcine rotavirus G9 in Japanese piglets with diarrhea: close relationship of their VP7 genes with those of recent human G9 strains. J Clin Microbiol 2005, 43:1377-1384.

37. Okitsu S, Khamrin P, Thongprachum A, Maneekarn N, Mizuguchi M, Ushiijima H: Predominance of porcine P[23] genotype rotaviruses in piglets with diarrhea in northern Thailand. $J$ Clin Microbiol 2011, 49:442-445.

38. Barreiros MA, Alfieri AA, Alfieri AF, Medici KC, Leite JP: An outbreak of diarrhoea in one-week-old piglets caused by group $A$ rotavirus genotypes P[7], G3 and P[7], G5. Vet Res Commun 2003, 27:505-512. 
39. Dewey C, Carman S, Pasma T, Josephson G, McEwen B: Relationship between group $A$ porcine rotavirus and management practices in swine herds in Ontario. Can Vet J 2003, 44:649-653.

40. Yuan L, Stevenson WG, Saif JL: Rotavirus and Reovirus. In Diseases of Swine.. 9 edition. Edited by: Straw EB, Zimmerman JJ, D'Allaire S, Taylor JD. Ames, lowa: Blackwell Publishing Professional; 2006:435-454.

\section{doi:10.1186/1297-9716-42-112}

Cite this article as: Miyazaki et al:: Genetic diversity of group A

rotaviruses associated with repeated outbreaks of diarrhea in a farrow-tofinish farm: identification of a porcine rotavirus strain bearing a novel VP7 genotype, G26. Veterinary Research 2011 42:112.

Submit your next manuscript to BioMed Central and take full advantage of:

- Convenient online submission

- Thorough peer review

- No space constraints or color figure charges

- Immediate publication on acceptance

- Inclusion in PubMed, CAS, Scopus and Google Scholar

- Research which is freely available for redistribution

Submit your manuscript at www.biomedcentral.com/submit
Ciomed Central 